\title{
O DIALOGISMO E A CLÍNICA DOS DISTÚRBIOS DE LINGUAGEM: IMPLICAÇÕES E PERSPECTIVAS
}

\author{
DIALOGISM AND CLINICAL DISORDERS OF LANGUAGE: IMPLICATIONS \\ AND PERSPECTIVES
}

\author{
Jefferson Lopes Cardoso \\ Docente da Universidade Federal do Rio Grande do Sul \\ Valdir do Nascimento Flores \\ Docente da Universidade Federal do Rio Grande do Sul. \\ Bolsista de Produtividade do CNPq
}

\begin{abstract}
RESUMO: Este texto apresenta alguns conceitos da teoria de Bakhtin para, a partir deles, abordar a questão da clínica dos distúrbios de linguagem na qual estes são, ao mesmo tempo, objeto de estudo e de intervenção. Após a apresentação e a articulação do referencial teórico, é proposto um deslocamento para uma abordagem do distúrbio de linguagem tendo em vista a eleição de aspectos clínicos. Metodologicamente, o trabalho articula os pressupostos teóricos do dialogismo a uma prática clínica voltada aos distúrbios de linguagem para responder a seguinte questão: como as noções bakhtinianas em torno da linguagem podem lançar novas luzes ao estudo dos distúrbios de linguagem? Conclui-se que o diálogo entre a teoria dialógica e o campo dos distúrbios de linguagem é produtivo para uma outra visão de clínica.

PALAVRAS-CHAVE: Distúrbio de linguagem; Dialogismo, Enunciação.
\end{abstract}

ABSTRACT: This paper presents some concepts of the theory of Bakhtin and, from them, to address the issue of clinical disorders of the language in which these are at the same time, the object of study and intervention. After the presentation and articulation of the theoretical framework, we propose a shift to an approach to language impairment in view of the election of clinical aspects. Methodologically, the work articulates the theoretical assumptions of dialogism to a clinical practice focused on language disorders to answer the following question: how Bakhtinian notions about language can shed new light on the study of language disorders? We conclude that the dialogue between the dialogic theory and the field of language disorders is productive for another view of clinica.

KEYWORDS: Langauge disorder; Dialogism; Enunciation.

\section{INTRODUÇÃO}

A clínica dos distúrbios de linguagem ${ }^{1}$ tem se configurado em um campo complexo de pesquisa e reflexão e isso se deve, basicamente, a um motivo: essa clínica é, desde a sua

\footnotetext{
${ }^{1}$ Utilizamos a expressão distúrbios de linguagem para denominar o conjunto das manifestações de linguagem observadas na instância clínica. Estão incluídas nessa designação desde manifestações decorrentes de problemas neuros-sensoriais, anatômicos, intelectuais, motores, neurológicos, de estrutura psíquica, entre outros, até as manifestações de linguagem presentes em quadros sindrômicos com ou sem etiologia orgânica definida. A definição do sintagma clínica dos distúrbios de linguagem é desenvolvida em Cardoso (2010). Por ora, cabe-nos dizer que estamos nos referindo ao campo de atuação da fonoaudiologia.
}

Work. Pap. Linguíst., 13(1): 25-40, Florianópolis, jan./mar, 2013 
origem, aberta a múltiplos diálogos teóricos e metodológicos, o que, consequentemente, a torna receptiva a uma série rica de influências - embora, nem sempre, confluentes.

Em outras palavras, a clínica voltada aos distúrbios de linguagem é um domínio que convoca saberes constituídos em várias esferas do conhecimento - medicina, psicologia, odontologia, linguística, psicanálise, entre outras - em função da natureza de seu interesse: o distúrbio de linguagem.

O distúrbio de linguagem é uma das formas de manifestação da linguagem humana que mais formula dificuldades ao pesquisador. Tomemos, a título de ilustração, um distúrbio como a gagueira. A simples observação de dados de gagueira é suficiente para levar à conclusão de que sua análise exige do pesquisador muito mais do que as metodologias stricto sensu estão habituadas a fornecer. Esse fenômeno não pode ser, por exemplo, integralmente explicado no contexto médico, nem no escopo da psicologia, nem da linguística. No que diz respeito, especificamente, à linguística - área de interesse neste trabalho, - uma dificuldade que salta aos olhos é o fato de que é evidente que a gagueira não está circunscrita ao que as teorias linguísticas, em geral, comumente consideram ser um nível da análise linguística. A gagueira não se limita apenas ao nível fonológico, por exemplo. Ela se manifesta simultaneamente nos níveis fonológico, morfológico, sintático e semântico, apenas para citar os mais referidos na literatura. Ou seja, o locutor, quando gagueja, o faz com a língua toda. Somente isso já bastaria para criar inúmeras dificuldades ao estudo linguístico da gagueira.

Enfim, a natureza heteróclita e multiforme, para usar uma expressão saussuriana, do distúrbio de linguagem impõe a essa clínica uma complexidade da qual dificilmente o fonoaudiólogo poderá se desviar no exercício de seu trabalho.

Em reconhecimento a isso é que este trabalho apresenta-se como um esforço para desenvolver dois objetivos. O primeiro - de ordem mais geral - busca contribuir com os estudos do campo do distúrbio de linguagem associando-o a uma discussão de natureza linguística. Em outras palavras: objetivamos contribuir no entendimento de algumas questões clínicas relacionadas ao distúrbio de linguagem. Esse objetivo se realiza, segundo pensamos, de forma indireta, neste texto, uma vez que acreditamos que refletir sobre aspectos da linguagem deve, indiretamente, contribuir para entender, ou conhecer, algumas faces de um campo que lida com a linguagem desde uma perspectiva clínica.

O segundo objetivo - de ordem mais específica - decorre do anterior e almeja apresentar uma reflexão específica acerca da linguagem como subsidiária à clínica dos distúrbios de linguagem. Esse último objetivo será levado a cabo a partir do recurso ao pensamento sobre a linguagem do filósofo Mikhail Bakhtin. Os motivos que nos levam a escolher a filosofia da linguagem estudada por Bakhtin e seus interlocutores contemporâneos do Círculo no campo da Linguística fícarão claros, esperamos, ao término deste texto. Porém, cabe indicar, desde já, um: Bakhtin é, por excelência, o autor que colocou no centro de sua investigação o diálogo. Cremos que a fonoaudiologia - como clínica voltada aos distúrbios de linguagem - muito se beneficiaria ao assumir o diálogo como o locus de sua intervenção. 
Finalmente, à guisa de introdução, cabe dizer que faremos, adiante, o seguinte percurso: na seção 2, apresentamos os conceitos e as noções que destacamos do pensamento bakhtiniano, como o diálogo, a enunciação, o enunciado e a significação; na seção seguinte refletimos acerca de alguns elementos da clínica a partir da leitura e da associação das ideias, já apontadas na seção anterior, sobre a teoria do dialogismo.

\section{ASPECTOS DO PENSAMENTO BAKHTINIANO}

Inúmeras são as possibilidades de acesso à reflexão sobre a linguagem desenvolvida por Mikhail Bakhtin. O conjunto dos trabalhos do autor é de tal forma diversificado que o recorte impõe-se ao leitor que quiser dele fazer algum uso.

Assim, também nós procedemos a um recorte: precisamos, inicialmente, as noções de dialogismo e diálogo (cf. 2.1) para, em seguida, enfatizarmos alguns dos aspectos que integram o que pode ser chamado de quadro enunciativo da teoria (cf. 2.2 e 2.3).

\subsection{DIALOGISMO E DIÁlogOS}

O termo dialogismo, apesar de notoriamente atribuído a Bakhtin, não é um termo que tenha largo uso no conjunto da reflexão do autor. O uso que Bakhtin faz dele permite dizer que dialogismo não tem um sentido único, sendo, portanto, um conceito reconstruído pelo autor a cada objeto de reflexão (a teoria do romance, a teoria da cultura, a teoria do conhecimento, a filosofia da linguagem etc.). $\mathrm{Na}$ verdade, Bakhtin desenvolve seus estudos sobre o dialogismo a partir da literatura, mas sugere sua existência em outros tipos de discursos, considerando-o, inclusive, como um fator geral constitutivo da linguagem.

Entre as características que podemos atribuir ao dialogismo, consideramos como um dos pontos essenciais a ênfase dada nas relações que o homem mantém com o mundo através da linguagem. Outro destaque é o entendimento da comunicação como relação de alteridade, constituidora do eu pelo reconhecimento do $t u$. Segundo Martins (1990), o princípio do dialogismo é construído a partir de um núcleo - a comunicação enquanto relação de alteridade. A autora ainda explica que o elemento que sustenta a teoria do dialogismo é a existência de um sujeito constituído numa relação de intersubjetividade linguística. A isso, gostaríamos de acrescentar que é possível ver as relações que o homem mantém com o mundo através da linguagem como um elemento associado à comunicação.

Para Bakhtin, a comunicação existe na reciprocidade do diálogo e significa muito mais que a transmissão de mensagens. Através da comunicação o homem constitui-se como sujeito (consciência) no auto-reconhecimento, pelo reconhecimento do outro, numa relação de alteridade. $\mathrm{O}$ ato de tomada de consciência de si próprio implica a existência do olhar do outro. Sob esse prisma, toda a comunicação tem um caráter intersubjetivo e dialógico, ocorrendo através da diferença, tanto entre pessoas, como entre textos e grupos sociais.

Na teoria do dialogismo, o diálogo ocupa uma posição central, podendo ser considerado o paradigma da criação bakhtiniana. O conceito de diálogo, em Bakhtin, está atrelado a 
outros aspectos relacionados ao estudo da linguagem. Entre esses aspectos, destaca-se a enunciação e, por conseguinte, o contexto e os sujeitos implicados na cena enunciativa. O diálogo em Bakhtin não é, como se entende no senso comum, uma simples conversa ou comunicação eficiente e harmônica entre pessoas, em que está presente uma argumentação, aceitação, consensualidade ou divergência entre dois sujeitos falantes, ou entre grupos.

Assim como a comunicação - entendida como uma relação de alteridade -, a noção de diálogo em Bakhtin está ligada à de alteridade. Se, segundo Bakhtin, é na relação com o outro que o sujeito adquire consciência de si, a intersubjetividade é condição para a comunicação, que se estabelece por meio de um material semiótico comum. O conteúdo da consciência possui uma natureza semiótica, ideológica e linguística, o que permite a sua existência e o seu desenvolvimento no diálogo. E isso ocorre mesmo que a atividade da consciência se desenvolva no discurso interior, pois mesmo assim ela é discurso, é diálogo do sujeito consigo mesmo. Assim, a consciência se constitui numa relação de alteridade, que é uma realidade discursiva.

Como destaca Bakhtin (1992), em Os gêneros do discurso, o diálogo, por sua clareza e simplicidade, é a forma clássica da comunicação verbal. É no diálogo real que a alternância dos sujeitos falantes, determinante das fronteiras do enunciado concreto, é observada de modo mais direto e evidente. As réplicas, ou seja, os enunciados dos interlocutores, alternam-se regularmente no diálogo. Cada réplica, mesmo a mais breve e fragmentária, possui um acabamento específico que expressa a posição do locutor, sendo passível de resposta (cf. adiante sobre posição responsiva). Com efeito, a alternância dos sujeitos falantes, que pode ser diversamente caracterizada e adotar formas variadas conforme as condições e situações da comunicação, se manifesta de forma mais clara no diálogo.

\subsection{LINGUAGEM E ENUNCIAÇÃO: O PRINICPIO DO EU E DO OUTRO}

Ao argumentar o seu ponto de vista em relação à linguagem, Bakhtin/ Voloschinov ${ }^{2}$ faz um exame de duas linhas do pensamento filosófico e linguístico ${ }^{3}$ difundidas até a contemporaneidade de seus estudos. Através do debate dessas posturas filosóficolinguísticas o autor discute o conceito de enunciação, relacionando-o à palavra e à língua como um fato social. No prosseguimento de suas críticas, ressalta também a importância do outro no processo de comunicação verbal, assim como o que está envolvido no ato de compreensão da linguagem.

O conceito de enunciação em Bakhtin/Voloschinov contempla a dualidade ofuscada de que falar e ouvir não são atividades exclusivas e integrais. As pessoas executam essas atividades simultaneamente, em uma situação específica. Essa inter-relação social é mediada pela palavra, produto da interação entre locutor e ouvinte e ponte entre os mesmos. A palavra, assim, comporta duas faces: procede de alguém e se dirige para outro alguém.

\footnotetext{
${ }^{2}$ No caso de Marxismo e filosofia da linguagem, usamos, para fins de referência, a indicação dupla de autoria tal como aparece na edição que utilizamos, a brasileira.

${ }^{3} \mathrm{O}$ subjetivismo idealista, perspectiva ligada ao pensamento de Wilhelm Humboldt e à escola de Vossler, e o objetivismo abstrato, por sua vez ligada ao pensamento de Ferdinand de Saussure.

Work. Pap. Linguíst., 13(1): 25-40, Florianópolis, jan./mar, 2013
} 
A palavra (e em geral, o signo) é interindividual. Tudo o que é dito, expresso, situa-se fora da "alma", fora do locutor, não lhe pertence com exclusividade. Não se pode deixar a palavra para o locutor apenas. $\mathrm{O}$ autor (o locutor) tem seus direitos imprescritíveis sobre a palavra, mas também o ouvinte tem seus direitos, e todos aqueles cujas vozes soam na palavra têm seus direitos (não existe palavra que não seja de alguém). A palavra é um drama com três personagens (não é um dueto, mas um trio). (Bakhtin, 1992, p. 350, grifo do autor)

Nessa direção, a palavra não pertence nem ao locutor, nem ao ouvinte totalmente. A cada um, cabe somente uma parte dela. Se pudéssemos afirmar que em algum momento o locutor é o único dono da palavra, esse momento seria apenas o do ato físiológico de sua materialização. Mas isso é pouco para justificar uma propriedade sobre a palavra.

Assim, a enunciação se caracteriza como o produto da interação de dois indivíduos socialmente organizados, sendo determinada pela situação social mais imediata e pelo meio social mais amplo. A enunciação, a atividade mental a exprimir e a cadeia verbal são de natureza social, contrariando o pensamento do subjetivismo idealista: "Só o grito inarticulado de um animal procede do interior, do aparelho fisiológico do indivíduo isolado" (BAKHTIN/VOLOSCHINOV, 1999, p.121).

Bakhtin/Voloschinov é crítico em relação à linguística de sua época que, na base de seus métodos de reflexão sobre a língua como sistema de formas normativas, utiliza procedimentos elaborados para o estudo das línguas mortas, que se mantêm em documentos históricos escritos. Segundo Bakhtin/Voloschinov, isso é resultado de uma influência do filologismo no pensamento da linguística europeia. Uma língua morta se apresenta como uma língua estrangeira para o linguista que a estuda, o que desvincula a enunciação monológica da esfera real, considerando-a como um todo isolado que se basta a si mesmo. A língua morta-escrita-estrangeira e a enunciação isolada monológica, desvinculada do contexto real, serviram de base à concepção de língua para a linguística.

No ponto de vista de Bakhtin/Voloschinov, a língua não se apresenta como um fato objetivo externo ao sujeito, nem como um sistema de normas rígidas e imutáveis. Para Bakhtin/Voloschinov, a língua se apresenta como uma corrente evolutiva ininterrupta. Por sua vez, a consciência subjetiva do locutor não se utiliza da língua como um sistema de formas normativas. Esse sistema é uma abstração. É o produto de uma reflexão sobre a língua que não procede da consciência do locutor nativo, e que não serve aos propósitos imediatos da comunicação.

$\mathrm{Na}$ verdade, o locutor utiliza a língua para suas necessidades enunciativas concretas, ou seja, para ele, a construção da língua está orientada no sentido da enunciação da fala. Estar de acordo com as formas normativas não é o essencial da língua, mas, sim, o deslocamento de significações que a forma adquire em determinado contexto

Sobre a palavra, o importante é a sua capacidade de significar. A significação da palavra é totalmente determinada por seu contexto e a multiplicidade de significações é o índice que faz de uma palavra uma palavra. Esse fato concede à palavra o seu estatuto de signo, caso contrário, se existisse uma única significação inerte e imutável, ela seria 
apenas um sinal. Se for sabido de antemão tudo o que a palavra pode dizer, se nada se espera dela, então ela se coisifica e se separa do diálogo.

O que importa realmente é que a "forma linguística" apareça como um signo variável e flexível, adequada às condições de uma situação concreta, e não como sinal estável e sempre idêntico. O sujeito não recebe a língua pronta para ser usada. Ele "mergulha" na corrente da comunicação verbal e, a partir desse momento, começa a se constituir enquanto sujeito falante. Assim, a língua pronta pode ser entendida como uma abstração, como, por exemplo, na aquisição de uma língua estrangeira. Nesse caso, a língua estrangeira é assimilada, e isto só é possível pelo fato de o sujeito já estar imerso em sua língua materna.

Para Bakhtin/Voloschinov, "os sujeitos não "adquirem” sua língua materna: é nela e por meio dela que ocorre o primeiro despertar da consciência" (1999, p.108, grifo dos autores). Dominamos a língua materna antes de estudar a sua gramática. A composição de seu léxico e sua estrutura gramatical não são aprendidas nos dicionários e nas gramáticas. Adquirimos a língua materna através dos enunciados concretos que ouvimos e falamos, no processo de comunicação verbal que se estabelece entre nós e os indivíduos que nos rodeiam.

Para o falante nativo, a palavra não se apresenta como um item no dicionário, mas como parte das mais diversas enunciações dos locutores $\mathrm{A}, \mathrm{B}$ ou $\mathrm{C}$ de sua comunidade e das múltiplas enunciações de sua própria prática linguística (Bakhtin/Voloschinov, 1999, p. 95).

Enfim, para Bakhtin/Voloschinov a língua não é um objeto abstrato ideal, sincrônico e homogêneo, que rejeita as manifestações individuais. A língua é um fato social, e por essa razão abarca a fala, a enunciação como sendo de natureza social. A fala está ligada às condições de comunicação que, por sua vez, estão sempre ligadas às estruturas sociais.

A crítica à tradição dos estudos linguísticos feita por Bakhtin/Voloschinov diz respeito, diretamente, à desconsideração do papel do outro no processo de comunicação verbal. Para os autores, é necessário considerar o papel e o ponto de vista do receptor, ou seja, do outro nesse processo. O uso da língua não pode ser considerado somente em relação ao locutor, como se este estivesse sozinho no mundo.

Nessa direção, encontramos o estatuto da palavra para o autor. Para Bakhtin (1997), em Problemas da poética de Dostoievski, a palavra não pode ser vista como "palavra impessoal da língua", mas como signo da posição semântica do outro. Nela, se ouve a voz do outro. Um indivíduo nunca encontra previamente a palavra como uma palavra neutra da língua. O indivíduo recebe a palavra da voz do outro, com suas aspirações e avaliações. No seu contexto, a palavra deriva de outro contexto, é impregnada de elucidações de outros. Ela está em contexto de outros e em lábios outros:

A palavra não é um objeto, mas um meio constantemente ativo, sempre mutável de comunicação dialógica. Ela nunca basta a uma consciência, a uma voz. Sua vida está na passagem de boca em boca, 
de um contexto para outro, de um grupo social para outro, de uma geração para outra. (BAKHTIN, 1997, p. 203).

Nesse sentido, o outro exerce um papel ativo no processo de comunicação verbal. Todo discurso é dirigido a um interlocutor. Todavia, esse interlocutor não é o outro exterior de um discurso, que recebe uma mensagem pronta. Locutor e ouvinte não são dois polos simétricos entre os quais passa uma informação. O discurso é construído pelos participantes do diálogo, é interindividual. Por essa perspectiva, o outro é a condição do discurso, ele participa na construção do sentido e instaura a heterogeneidade no discurso.

Na participação do outro no processo de comunicação verbal, é preciso fazer uma distinção entre as noções bakhtinianas de reconhecimento e de compreensão. Para Bakhtin, o reconhecimento é o processo de identificação da forma linguística. Assim ocorre, por exemplo, quando identificamos um sinal. O sinal é apenas um instrumento para designar um objeto ou um acontecimento preciso e imutável. Outro exemplo de reconhecimento, apontado por Bakhtin, é percebido em alguns métodos de ensino de uma língua estrangeira. Nesses processos, os componentes da língua são assimilados como sinais, ou seja, a palavra é isolada de seu contexto e inscrita num caderno para ser aprendida. A forma é assimilada no sistema abstrato da língua, como uma forma sempre idêntica a si mesma.

De maneira diferente, a compreensão não é uma simples percepção do componente normativo do signo linguístico, ou seja, a percepção do signo como objeto sinal. No processo de compreensão, o signo é compreendido num contexto concreto, sua significação pertence a uma enunciação particular. Isso ocorre porque o signo é variável e flexível, pois pode mudar sua significação conforme o contexto em que aparece. Bakhtin focaliza sua atenção no falante que participa numa enunciação concreta, em que a palavra é um signo adaptável e mutável, e não um sinal estável e sempre auto equivalente. Bakhtin/Voloschinov ressaltam que, mesmo nas primeiras fases da aquisição da linguagem, não há pura "sinalidade", pois a forma já está relacionada a um contexto, portanto, já é signo.

É por essa relação com o outro que todo ato de compreensão implica uma resposta. Implica a oposição de uma contrapalavra à palavra do locutor. Somente na compreensão de uma língua estrangeira é que se procura encontrar para cada palavra uma palavra equivalente na própria língua. Com efeito, não há razão para dizer que a significação pertence à palavra. Quanto à localização e à origem da palavra, Bakhtin /Voloschinov enfatizam que:

$\mathrm{Na}$ verdade, a significação pertence a uma palavra enquanto traço de união entre os interlocutores, isto é, ela só se realiza no processo de compreensão ativa e responsiva. A significação não está na palavra nem na alma do falante, assim como também não está na alma do interlocutor. Ela é o efeito da interação do locutor e do receptor produzido através do material de um determinado complexo sonoro. É como uma faísca elétrica que só se produz quando há contato dos dois polos opostos (1999, p. 132, grifo dos autores) 
Podemos dizer, apoiados em Bakhtin/Voloschinov, que a significação e a compreensão se encontram em uma relação de dependência mútua. $\mathrm{O}$ único meio pelo qual a palavra pode significar é ser compreendida. Essa compreensão é construída por locutores e ouvintes particulares, que também são locutores em situações específicas. Portanto, não existe significado ou compreensão fora da interação linguística. A compreensão da linguagem é uma tomada de posição ativa sobre o que é dito. É ativa na medida em que contém o germe de uma resposta.

Ao abordar o processo de compreensão da linguagem como uma tomada de posição ativa sobre o que é dito, Bakhtin discorda das funções "ouvinte" e "receptor" tal como são abordadas pela linguística de sua época. Para ele, o esquema dos processos "ativos" da fala no locutor e dos processos "passivos" de percepção na fala do ouvinte dão uma imagem distorcida do processo complexo da comunicação verbal. Isso não quer dizer que esses esquemas não correspondam a certos aspectos reais. O problema é quando são utilizadas para representar o "todo real" da comunicação verbal. Nesse caso, Bakhtin (1992) afirma que não passam de uma ficção científica.

Para o filósofo, o ouvinte adota sempre uma atitude responsiva ativa com relação ao enunciado do locutor. Ele concorda ou discorda, total ou parcialmente, completa, adapta ou mesmo apronta-se para responder durante todo processo de audição e de compreensão do enunciado. Muitas das vezes, essa elaboração já ocorre nas primeiras palavras emitidas pelo locutor. Sobre a atitude responsiva ativa do ouvinte, o autor, em Os gêneros do discurso, diz:

A compreensão de uma fala viva, de um enunciado vivo é sempre acompanhada de uma atitude responsiva ativa (conquanto o grau dessa atividade seja muito variável); toda compreensão é prenhe de resposta e, de uma forma ou de outra, forçosamente a produz: o ouvinte trona-se locutor. A compreensão passiva das significações do discurso ouvido é apenas o elemento abstrato de um fato real que é o todo constituído pela compreensão responsiva ativa e que se materializa no ato real da resposta fônica subsequente. (BAKHTIN, 1992, p. 290, grifo do autor).

Realmente, o que o locutor espera é uma compreensão responsiva ativa de seu interlocutor, pois, do contrário, apenas teria o seu pensamento duplicado na fala do outro. O que o locutor espera é uma concordância, uma adesão, uma objeção, uma discordância, etc. Observamos ainda que o próprio locutor é, em certa medida, um respondente, pois ele não é o primeiro a romper o silêncio de um mundo mudo. Antes mesmo de seu discurso já existem enunciados anteriores, provenientes dele mesmo ou do outro.

\subsection{O ENUNCIADO E A QUESTÃO DO SENTIDO}

O conceito de enunciado em Bakhtin está atrelado à noção de gêneros do discurso, pois os gêneros englobam os tipos relativamente estáveis de enunciados, elaborados pelas "esferas de utilização da língua". Essas esferas são representadas pelas áreas da atividade humana, e a materialização da língua ocorre sob a forma de enunciados, orais e escritos, que se originam de indivíduos pertencentes às respectivas áreas.

Work. Pap. Linguíst., 13(1): 25-40, Florianópolis, jan./mar, 2013 
Bakhtin (1992), faz referência ao leque variado dos gêneros do discurso, assim como faz uma distinção entre gênero primário e secundário ${ }^{4}$. O gênero secundário se apresenta em um grau mais complexo que o primário, visto que o secundário surge de situações refletidas culturalmente, geralmente em composições escritas, artísticas, científicas ou sócio-políticas. Para Bakhtin, o romance, assim como a réplica do diálogo cotidiano é um enunciado, sendo que o que os diferencia é o grau de complexidade. A diferenciação entre os dois tipos de gênero é importante, pois é através da análise de ambos que a natureza do enunciado é elucidada.

Bakhtin assinala que, em qualquer área de estudo linguístico, deve-se levar em conta a natureza do enunciado e as particularidades de gênero que evidenciam a variedade do discurso. Para o autor, desconsiderar essa natureza leva ao enfraquecimento da relação existente entre a língua e a vida. "A língua penetra na vida através dos enunciados concretos que a realizam, e é também através dos enunciados concretos que a vida penetra na língua" (BAKHTIN, 1992, p.282). É assim que o gênero do discurso é uma forma do enunciado e não uma forma da língua. Ele está intrinsecamente relacionado a circunstâncias e a temas específicos da comunicação verbal.

Conceitualmente, o todo do enunciado é composto por três elementos: conteúdo temático, estilo verbal ${ }^{5}$ (recursos lexicais, fraseológicos e gramaticais) e construção composicional $^{6}$. É através da fusão desses elementos que o enunciado vai refletir as condições específicas e as finalidades de determinada esfera de comunicação ${ }^{7}$.

Bakhtin (1992) faz uma distinção, que julgamos fundamental, entre enunciado e discurso. Segundo o autor, a palavra "discurso" não teve, historicamente, uma definição única, o que a levou ser utilizada indiferentemente como "enunciado", mas também como língua, fala, como uma sequência de enunciados, etc. Isso conduziu ao entendimento de que a palavra "discurso" se refere a qualquer "enunciado", de qualquer locutor, o que para Bakhtin não é verdadeiro. Na concepção clássica, o discurso é dividido em orações, que podem dividir-se em combinações de palavras, e essas palavras podem, sucessivamente, se decompor em sílabas e essas em fonemas. Ou seja, para Bakhtin, discurso e enunciado são duas palavras distintas, que significam coisas diferentes.

Para argumentar em prol da diferença, Bakhtin (1992)exemplifica com um enunciado do tipo "Ah!" - réplica do diálogo. Ao analisarmos esse enunciado, vemos que o

\footnotetext{
${ }^{4} \mathrm{O}$ gênero primário abarca a réplica do diálogo cotidiano, o relato familiar, a carta informal, a ordem militar, as declarações públicas, etc., enquanto o secundário compreende o romance, o teatro, o discurso científico, etc.

${ }^{5} \mathrm{O}$ estilo participa como elemento na unidade de gênero de um enunciado, pertencendo a um gênero peculiar de uma respectiva esfera da atividade e da comunicação humana. Assim como ele está fortemente ligado ao enunciado, está vinculado à composição do mesmo.

${ }^{6}$ Por composição de um enunciado, entende-se: o tipo de estruturação e de conclusão de um todo e o tipo de relação entre o locutor e os outros parceiros da comunicação verbal, como a relação do locutor com o ouvinte, com o leitor, com o discurso do outro, etc.

${ }^{7}$ As esferas da atividade humana e da comunicação compreendem: as réplicas do diálogo cotidiano em toda a sua diversidade formal, crônicas, contratos, escritos literários, científicos, cartas oficiais e pessoais, textos legislativos, etc.
}

Work. Pap. Linguíst., 13(1): 25-40, Florianópolis, jan./mar, 2013 
mesmo não é divisível em orações, nem em combinações de palavras ou sílabas. Isso mostra que, se seguirmos o raciocínio clássico, nem todo enunciado é um discurso.

Em Bakhtin, o discurso é uma forma particular de ação - uma ação linguística. O discurso é a língua em sua integridade concreta e viva, ou seja, a língua do ponto de vista da enunciação e não como objeto específico da linguística. O discurso é uma ponte lançada entre duas pessoas socialmente determinadas e, por essa razão, pode ser entendido como um fenômeno de comunicação cultural, compreendendo o falante, o ouvinte, o tópico e a situação social que o engendra. O discurso é dialógico ${ }^{8}$.

Ao estudarmos o enunciado enquanto unidade real da comunicação verbal, podemos compreender melhor as unidades da língua como sistema, ou seja, as palavras e as orações. Para Bakhtin (1992) enunciado e oração são coisas diferentes, e é dessa forma que devem ser tratadas.

A oração, como uma unidade da língua, é de natureza gramatical, suas fronteiras não são marcadas pela alternância dos sujeitos falantes e, portanto, não está em relação imediata com os enunciados do outro. Também não está em contato imediato com a realidade, com a situação extraverbal. O seu contexto é o do discurso de um único e mesmo falante, pois representa um pensamento relativamente acabado, relacionado com outros pensamentos do mesmo locutor.

Se, por outro lado, a oração for considerada como elemento significante do enunciado em seu todo, ela adquire sentido dentro desse todo. Isso quer dizer que, se considerarmos o contexto, os enunciados precedentes e subsequentes, e os sujeitos participantes do diálogo, a oração passa à categoria de enunciado completo, deixando de ser somente uma parte restrita do mesmo. Ao passar à categoria de enunciado completo, a oração é dotada de um sentido e não somente de uma significação, sendo observadas as condições concretas de sua utilização na comunicação verbal.

Julgamos pertinente nesse momento mencionar a distinção feita por Bakhtin /Voloschinov, em Marxismo e filosofia da linguagem (1999), entre tema e significação. Nessa obra é considerada a existência de dois níveis semânticos, que estão dialeticamente relacionados - a significação e o tema. Para Bakhtin/Voloschinov o significado como um todo inclui tanto a significação como o tema. Porém, há uma distinção que precisa ser feita entre esses dois níveis.

O tema é o sentido da enunciação completa, podendo inclusive pertencer a uma palavra isolada, desde que esta opere como uma enunciação global. Ele é único e, por isso, serve de base para a definição da enunciação. É individual e não reiterável, como a enunciação, e caracterizado pela transitoriedade, visto que o seu sentido é adequado unicamente ao momento da fala. O tema se apresenta como a expressão de uma situação

\footnotetext{
${ }^{8}$ Falamos aqui de um entendimento generalizado de discurso em Bakhtin, visto que, ao analisar, por exemplo, o romance de Dostoiévski, em Problemas da Poética de Dostoievski, Bakhtin (1997) classifica uma série de tipos de discurso, dividindo-os em "monovocais": discurso referencial direto, que visa à interpretação referencial e direta do objeto; discurso objetificado ou representado, que tem significação objetiva imediata mas não se situa no mesmo plano ao lado do discurso do autor - discurso "bivocal" e suas variações, como sendo o discurso orientado para o outro.
}

Work. Pap. Linguíst., 13(1): 25-40, Florianópolis, jan./mar, 2013 
histórica concreta que deu origem à enunciação. O tema da enunciação é concreto, sendo determinado pelas formas linguísticas (palavras, formas sintáticas, os sons, as entoações) e pelos elementos não verbais da situação. Os elementos da situação são tão importantes quanto às formas linguísticas, como afirma Bakhtin/Voloschinov: "Se perdermos de vista os elementos da situação, estaremos tão pouco aptos a compreender a enunciação como se perdêssemos suas palavras mais importantes". (BAKHTIN/VOLOSCHINOV, 1999, p.128)

A significação também faz parte da enunciação, podendo ser considerada como um aparato técnico para a realização do tema. Ela é formada pelos elementos da enunciação que são reiteráveis e idênticos cada vez que são repetidos. São elementos abstratos e convencionados. A significação está no interior do tema, e ao contrário deste, pode ser analisada em um conjunto de significações ligadas aos elementos linguísticos que a compõem ${ }^{9}$.

Não existe fronteira absoluta entre o tema e a significação, sendo que ambos são dependentes mutuamente. A inter-relação do tema e da significação é formulada por Bakhtin /Voloschinov como: o tema é o estágio superior real da capacidade linguística de significar, enquanto a significação é o estágio inferior. Para a investigação do significado de um determinado elemento linguístico elege-se um dos estágios como orientador, conforme o entendimento que se tem do funcionamento da linguagem. No caso do estágio superior, a investigação irá em busca do sentido contextual de uma dada palavra nas condições de uma enunciação completa. No segundo caso, do estágio inferior, a investigação da significação da palavra se realizará no campo do sistema da língua, ou seja, da palavra dicionarizada. Como podemos perceber, para Bakhtin/ Voloschinov somente o tema significa de maneira determinada, sendo a significação apenas um potencial, uma possibilidade de significar no interior de um tema concreto. Segundo suas palavras, a significação é absorvida pelo tema:

[...] a significação, elemento abstrato igual a si mesmo, é absorvida pelo tema, e dilacerada por suas contradições vivas, para retornar enfim sob a forma de uma nova significação com uma estabilidade e uma identidade igualmente provisórias. (BAKHTIN/VOLOSCHINOV, 1999, 136)

Especificamente sobre diferenciação entre oração e enunciado, Bakhtin aponta para o fato de que as pessoas não trocam orações, tampouco palavras, como unidades significantes da língua. Trocamos enunciados, constituídos com a ajuda de unidades da língua (palavras, combinações de palavras, orações). Uma oração pode ser reiterada, como no caso da repetição e da autocitação, dentro dos limites de um único e mesmo enunciado, porém, cada ocorrência representa um novo fragmento de enunciado. Quando reiterada, a oração muda sua posição e função no todo do enunciado.

\footnotetext{
${ }^{9}$ Bakhtin (1999) cita como exemplo para a diferenciação entre tema e significação a enunciação: “Que horas são?". Enquanto tema, essa enunciação tem um sentido diferente cada vez que é usada, pois está relacionada a uma situação histórica concreta, não podendo ser segmentada. Por outro lado, sua significação é análoga em todas as situações históricas em que é falada. A significação dessa enunciação é composta das significações de todas as palavras que fazem parte dela, das formas morfológicas, sintáticas, sons e entoações.
}

Work. Pap. Linguíst., 13(1): 25-40, Florianópolis, jan./mar, 2013 
A constituição do enunciado pode ser formada a partir de uma única oração, de uma única palavra, de uma única unidade da fala. Mas não é isso que transforma uma unidade da língua em uma unidade da comunicação verbal. O enunciado possui características específicas que lhe conferem o posto de unidade da comunicação verbal. A primeira característica é ser composto pela alternância dos sujeitos falantes e assim estar vinculado a outros enunciados na cadeia verbal. A segunda característica do enunciado é o seu acabamento específico, que é determinado por meio de critérios particulares, como a possibilidade de ser respondido. A terceira característica do enunciado diz respeito a sua relação com o locutor e com os outros parceiros da comunicação verbal.

O enunciado também é constituído de expressividade, ou seja, da relação valorativa que o locutor estabelece com o objeto do discurso, que vai variar conforme as esferas de comunicação verbal. Toda palavra usada na fala real possui um acento de valor ou apreciativo, isto é, quando um conteúdo objetivo é dito, ou escrito, ele é sempre acompanhado por um acento de valor determinado. A entonação é um dos recursos para expressar a relação emotivo-valorativa do locutor como o objeto de seu discurso. Sem acento apreciativo não há palavra. Uma palavra pode significar coisas diferentes dependendo da entonação em que são emitidas em determinado contexto ${ }^{10}$.

A entonação é de fundamental importância, pois permite expandir a capacidade das mesmas velhas palavras de atender a novas e irrepetíveis situações. Mas, a entonação expressiva não pertence à palavra como signo, mas ao enunciado acabado e com um sentido concreto. No sistema da língua, ou seja, fora do enunciado ela não existe. Ao escolhermos uma palavra, e baseados no todo do enunciado, construímos um todo intencional que é sempre expressivo. $\mathrm{O}$ ato da expressividade é provocado pelo contato entre a língua e a realidade, o que só ocorre através do enunciado. Dessa forma, a expressividade se apresenta como uma particularidade constitutiva do enunciado.

A expressividade, como constitutiva do enunciado, manifesta, além da relação do locutor com o objeto do enunciado, a relação do mesmo locutor com os enunciados do outro. São essas relações que fazem do enunciado uma unidade de caráter dialógico, onde o autor, o destinatário e a situação estão implicados na construção do sentido.

Assim como a expressividade, que supõe um autor, o enunciado está sempre voltado para um destinatário ${ }^{11}$. O fato de dirigir-se a alguém também é uma particularidade constitutiva do enunciado. Com efeito, a diversidade dos gêneros do discurso, mencionada anteriormente, é determinada pelas diversas formas típicas de dirigir-se a alguém e as diversas concepções típicas do destinatário. Cada um dos gêneros do

\footnotetext{
${ }^{10} \mathrm{Em}$ Os gêneros do discurso (1992), Bakhtin cita vários exemplos de enunciados que correspondem a um determinado gênero do discurso, expressando um valor, onde a entonação é o elemento chave como por exemplo: “ótimo!”, “ânimo!”, “burro!", etc. Destaca que, numa determinada situação, a palavra pode adquirir um sentido profundamente expressivo em forma de enunciado exclamativo, e que, se uma palavra isolada é proferida com uma entonação expressiva, já não é uma palavra, mas um enunciado completo.

${ }^{11}$ Bakhtin (1992) entende o destinatário não como necessariamente o interlocutor real, participante da interlocução imediata. $\mathrm{O}$ destinatário pode ser tanto o parceiro e interlocutor direto do diálogo na vida cotidiana, como o conjunto de especialistas em alguma área especializada da comunicação cultural, uma classe específica como a dos partidários, dos inimigos, dos chefes, dos subalternos, etc.
}

Work. Pap. Linguíst., 13(1): 25-40, Florianópolis, jan./mar, 2013 
discurso, em cada uma das áreas da comunicação verbal, tem o seu modelo de destinatário que o determina como gênero.

Após os aspectos acima considerados, podemos entender o enunciado como um fenômeno complexo, e, para entendermos sua natureza, é necessário que o analisemos em sua relação com o autor e com os outros enunciados no plano do objeto do sentido. O enunciado é um elo na cadeia de comunicação verbal. Suas fronteiras são determinadas pela alternância dos sujeitos falantes, sendo que dentro dessas fronteiras o enunciado reflete o processo verbal, os enunciados dos outros e os elos anteriores. Por essa razão, o objeto de discurso de um locutor nunca é inédito, pois o locutor não é o primeiro a falar dele. Como diz Bakhtin (1992), somente o Adão bíblico poderia ser o primeiro a nomear os objetos ainda não designados, escapando ao aspecto dialógico instaurado pelo já dito da palavra do outro. Mas, ao contrário do objeto de discurso, o enunciado não é o reflexo de algo que lhe preexiste, que está fora dele como algo dado. O enunciado sempre cria algo que antes dele não existira, algo novo que está sempre relacionado com um valor (a verdade, o bem, a beleza, etc.). Porém, essa criação é formulada a partir de algo dado - a língua, o fenômeno observado na realidade, o sujeito falante, etc. Estabelece-se então um processo, onde o dado se transforma no criado. Tudo que é criado se cria a partir de algo que é dado, como um sentimento vivido. $\mathrm{O}$ todo do enunciado não é uma unidade da língua, mas sim a unidade da comunicação verbal, e, como tal, é completo e irreproduzível.

O enunciado concreto coloca frente a frente os participantes de uma determinada situação, instaurando-os como co-participantes dessa situação. Nessa perspectiva, temos presente tanto o componente verbal, extraído do enunciado, como o componente extra verbal, proporcionado pela enunciação. Assim, a enunciação é constitutiva do enunciado e, dessa forma, concorre, juntamente com o primeiro, para a construção do sentido no processo de comunicação verbal. O todo do enunciado não se constitui somente por elementos linguísticos, mas também por elementos extralinguísticos, e por sua relação com outros enunciados. Sua natureza é dialógica, e, por essa razão, está vinculado a outros enunciados por uma relação dialógica.

\section{CONSIDERAÇÕES FINAIS: O DIALOGISMO E A CLÍNICA DOS DISTÚRBIOS DE LINGUAGEM}

Com certeza, as observações feitas acima a respeito do pensamento bakhtiniano acerca da linguagem não esgotam as possibilidades de entendimento da teoria do autor e Círculo, porém, parece-nos suficiente para indicar uma primeira aproximação entre o estudo dos distúrbios de linguagem e a referida teoria, tendo em vista as implicações ligadas à clínica.

Caberia, portanto, aqui, responder, mesmo que de forma inicial, a seguinte questão: como as noções sintetizadas, anteriormente, da obra de Bakhtin e Círculo podem lançar novas luzes no estudo dos distúrbios de linguagem?

Inicialmente, vale considerar que, na obra dos autores, o nosso interesse se voltou para a abordagem filosófico-linguística da linguagem, ancorada na teoria do dialogismo. Fazemos questão de frisar um dos pontos fundamentais que justificam, para nós, a 
interlocução entre o campo dos distúrbios de linguagem e a teoria do dialogismo: o fato de o dialogismo abranger e relacionar aspectos referentes à linguagem, à comunicação, à língua, ao sujeito, à fala e ao sentido. Cremos que esses são aspectos centrais na clínica dos distúrbios de linguagem

Cremos que a primeira consideração que deve ser levada em conta diz respeito à natureza dialógica da linguagem. A partir dessa concepção, a clínica voltada aos distúrbios de linguagem não pode abdicar da figura do locutor, nem da do interlocutor. Tal obviedade merece maior esclarecimento: parece evidente que o distúrbio diz respeito à dimensão de uso da linguagem e também àquele que a usa. Ora, não se pode ignorar que o distúrbio de linguagem não é separado daquele que o enuncia.

O dialogismo coloca em relevo algo que é muito caro aos estudos do distúrbio de linguagem: o fato de que o locutor enuncia algo para alguém. Trata-se, portanto, de uma relação na qual os sujeitos estão presentes em suas manifestações e nos pontos de vista assumidos diante do dizer. Os sujeitos portadores de algum distúrbio de linguagem utilizam de modo singular a linguagem. Valorizar isso é reconhecer na interlocução um esforço interpretativo no qual se ancoram o funcionamento linguístico e a presença de alteridade e linguagem.

Entre suas críticas à linguística, Bakhtin cita a desconsideração do papel do outro na linguagem. Para ele, o outro é a condição do discurso, participando na construção do sentido e, portanto, exercendo um papel ativo no ato de linguagem.

Na clínica que se ocupa do distúrbio de linguagem o sujeito em tratamento não pode, como é fato em algumas abordagens terapêuticas, ser levado a ocupar um lugar de repetidor de palavras. Num enfoque clínico dessa natureza, o sujeito em tratamento é considerado um interlocutor aprendiz, onde o ensinamento da linguagem é o objetivo a ser desempenhado por um interlocutor mais hábil - o fonoaudiólogo. Ao "outro", resta, nesse caso, uma posição passiva, aquela em que não há construção de sentido e alteridade no diálogo.

Bakhtin defende que a língua deve ser compreendida em sua integridade concreta e viva, enquanto discurso-fala, pois é na fala que a língua se materializa. Por meio da fala, ocorre um processo considerado central na teoria do dialogismo: a existência de um sujeito que se constitui numa relação de intersubjetividade linguística, ou seja, o falante torna-se sujeito através de um processo de alteridade. Assim, o campo de emergência do fenômeno linguístico é delineado pela alteridade dialógica estabelecida entre os sujeitos. É a língua posta em ação, através do discurso, que se desenvolve num aqui e agora, num presente fugaz. Perfilados, encontramos o linguístico e a enunciação.

Quando a situação, única e particular, é considerada no processo de comunicação verbal, há uma co-referência à enunciação, cujo estudo contempla o fenômeno da fala enquanto atividade de linguagem. A enunciação é construída a partir de uma interrelação social, que é mediada pela palavra, que é o produto da interação entre locutor e ouvinte. A existência da palavra está na passagem de um contexto para outro, de um sujeito para outro. 
A segunda consideração que fazemos é que não basta que a relação interlocutiva seja considerada. É necessário que esta seja suposta em um quadro não-simétrico da enunciação. No caso do distúrbio de linguagem, trata-se de colocar o processo em relevo e não o produto. É de suma importância poder "ouvir" a enunciação do locutor na língua e como, por esse ato, ele se propõe como sujeito.

Nesse sentido, o não-simétrico diz respeito ao fato de os sujeitos se proporem como tais a partir da própria fala na relação com o outro - e isso se dá com ou sem distúrbio. Enunciar é, assim, um exercício de troca que somente é possível no exercício da língua.

Portanto, o distúrbio de linguagem não deve ficar resumido a uma desordem de caráter funcional (articulatório e/ou rítmico), assim como o tratamento fonoaudiológico não pode ser resumido a um mero treinamento articulatório da fala. Contrariando a concepção bakhtiniana de linguagem, encontramos alguns métodos clínicos que visam o exercício da linguagem através da construção de orações. Esses métodos preconizam que a linguagem é dividida em sentenças, palavras, sílabas e fonemas. E por assim entenderem, o foco do tratamento é voltado para o agrupamento de palavras até a formação de orações. Como vimos, essa noção de oração é rejeitada por Bakhtin/Voloschinov, pois a oração, diferente do enunciado, não tem fronteiras marcadas pela alternância dos sujeitos falantes.

Na constituição de um "fato de linguagem" é indispensável que não se considere apenas o aspecto físico, o psíquico e o físiológico envolvidos no processo de comunicação. Tampouco não é suficiente uma abordagem da língua baseada no estudo da face sonora do signo linguístico, nem a vinculação entre o processo físiológico de produção do som ao de percepção sonora pelo homem, e muito menos o pensamento de que a atividade da linguagem é um ato de expressão da consciência individual. Para Bakhtin/Voloschinov, a essência da linguagem está na inter-relação do conjunto físico-psíquico-físiológico com a língua e com a fala, através do meio social e do contexto social imediato da situação de comunicação que envolve os sujeitos falantes.

Dito isso, não é possível conceber uma intervenção clínica cujo enfoque fique restrito ao ensinamento da produção de fonemas da língua. Em diferentes abordagens terapêuticas fonoaudiológicas, a língua é entendida como um sistema de sons. Nessa acepção, o distúrbio de linguagem é sinônimo de alteração gramatical ou de uma disfunção na execução neuromotora. Como dito em Bakhtin/Voloschinov, o sujeito não se utiliza da língua como um sistema de formas normativas, mas, sim, para suas necessidades enunciativas concretas. A língua não é um sistema de normas rígidas que se apresenta como um fato externo ao sujeito.

No cerne do dialogismo está a ideia de que a língua é um fato social, assim como a fala e o sujeito têm uma natureza social. Através de seus pressupostos teóricos Bakhtin fundamenta que o fenômeno da interação verbal é o essencial da língua, sendo este um fenômeno de caráter dialógico que abrange não apenas a língua como um sistema homogêneo de signos, mas também a fala como atividade constitutiva do sujeito e da própria língua. Entendemos que essas são razões suficientes para o produtivo diálogo entre a teoria do dialogismo e o campo dos distúrbios de linguagem. 


\section{REFERÊNCIAS}

BAKHTIN, M. M. Problemas da Poética de Dostoievski. Rio de Janeiro: ForenseUniversitária, 1997.

. (Voloschinov). Marxismo e Filosofia da Linguagem. São Paulo: Hucitec, 1999.

Fontes, 1992.

Os gêneros do discurso. In: Estética da Criação Verbal. São Paulo: Martins 1992.

O problema do texto. In: Estética da Criação Verbal. São Paulo: Martins Fontes, $\overline{\text { Fontes, }} 1992$.

Os estudos literários hoje. In: Estética da Criação Verbal. São Paulo: Martins

. Apontamentos 1970-1971. In: Estética da Criação Verbal. São Paulo: Martins Fontes, 1992.

- Observações sobre a epistemologia das ciências humanas. In: Estética da Criação Verbal. São Paulo: Martins Fontes, 1992. 1988.

Questões de Estética e Literatura: a teoria do romance. São Paulo: Hucitec,

BOUKHARAEVA, Louiza M. Começando o diálogo com Mikhail Mikhailovitch Bakhtin. Ijuí: UNIJUÍ, 1997.

CARDOSO, J.L. Princípios de análise enunciativa na clínica dos distúrbios de linguagem. 2010. 106 f. Tese (Doutorado em Letras). Programa de Pós-graduação em Letras, Universidade Federal do Rio Grande do Sul, Porto Alegre.

. Dialogismo e fonoaudiologia: a intersubjetividade na clínica. 2002. $208 \mathrm{f}$. Dissertação (Mestrado em Letras). Programa de Pós-graduação em Letras Universidade Federal do Rio Grande do Sul, Porto Alegre.

MARTINS, Eleni Jacques. Enunciação e diálogo. São Paulo, Editora da UNICAMP, 1990.

Recebido: 03/06/2013

Aceito: 30/06/2013 